\title{
Implementation of Andragogy Theory in Arabic Learning Class XII at Islamic Senior High School Azzhahiriyah
}

\author{
M. Givi Efgivia ${ }^{1 *}$, Farrah Zhahiriyah ${ }^{2}$, Marfie Widiyanti $^{3}$, Emelinny Iskandar $^{4}$ \\ ${ }_{1,2,3,4}$ Postgraduate Educational Technology, University of Ibnu Khaldun Bogor Indonesia \\ *Corresponding author email:mgivi@uika-bogor.ac.id
}

\begin{abstract}
The success of a nation's education is largely determined by the approach used by educators in delivering learning materials to students and currently many approaches have been developed by experts both targeting children and adults, including the concept of andragogy education which is expected to be a balancer. and at the same time an effort to cover the shortcomings that exist in the concept of education for adults. Andragogy as a form of educational concept that makes a learning process that involves adult learners into a learning experience structure. In learning Arabic there is a problem when high school starts to study the same material as the material at the junior high school level, educators must treat students like adults in the learning process so that students can understand concepts and understand learning so that they are able to develop abilities, enrich knowledge, improve qualifications, and competence of students. This study focuses on the process of learning Arabic at Islamic Senior High School Azzhahiriyah, with an andragogy approach, it is hoped that learning will be more effective.
\end{abstract}

Keywords: Andragogy, Arabic, Learning Theory

\section{INTRODUCTION}

The educational process is a very complex thing, because it involves many interrelated elements ranging from educators, students, facilities and infrastructure, methods, strategies, media and others. Education is not only about results, but also the process of achieving results by improving, improving, changing the knowledge, skills, and attitudes and behavior of students in an effort to educate human life through learning guidance activities. As stated in Law Number 20 of 2003 concerning the national education system, that national education aims to develop the potential of students to become human beings who believe, fear God Almighty, have noble character, are healthy, knowledgeable, capable, creative, independent. and become a democratic and responsible citizen. From this it can be seen that there are many goals to be achieved by the ongoing educational process which is realized from classroom learning.

Education should be able to produce human resources who have complete competencies, namely attitude competencies, knowledge competencies, and integrated skills competencies (Majid \& Rochman, 2014). So that in the world of education, an educator must really understand the components in the learning system. These components are important to understand, so that an educator can educate better and more efficiently. The components include: learning objectives, learning materials, learning methods, learning resources and evaluation (Sutikno, 2014).

In the learning process, learning theory has a very important role, because learning theory will determine how the learning process occurs. Before designing learning, educators must master a number of theories about learning, including several approaches to learning. Mastery of this theory is intended so that educators are able to scientifically account for their teaching behavior in front of the class. Broadly speaking, learning theory is always associated with the scope of the field of psychology or in other words, when talking about learning problems, it means talking about the human figure. This can be interpreted that there are several aspects that must receive attention. These aspects are cognitive, affective and psychomotor. Through these learning theories, educators will understand the various ways in which students learn and then link their principles and laws with teaching techniques to achieve memorable learning.

The term "andragogy" was first used by Alexander Kapp a high school teacher in Germany in 1833, he wrote a book entitled "Plato's 
Educational Ideas" which explained the importance of lifelong learning. The term andragogy was debated and then discontinued until Rosenstock wrote in 1921 which said that adult education requires teachers, methods and a special philosophy called andragogy. In 1926 Eduard Christian Lindeman wrote "Meaning of Adult Education" saying that Andragogy or adult education is an educational process that is not limited to classes or a formal curriculum. Andragogy tends to overcome daily life problems, not ideal abilities, andragogy is carried out based on conditions and situations not based on teaching materials. The curriculum is made based on the needs, tendencies and experiences of students. According to Lindeman, learning is learning to face life and all life is learning, so education never stops.

Lindeman's "Meaning of Adult Education" inspired Malcolm Shepherd Knowles to write and introduce the term "andragogy" into American literature in 1968. Knowles tried to lay the foundations of the concept of andragogy very clearly. According to Knowles, the best educational experiences are cooperative ones, guided by interactions between educators and learners with many available resources. During this experience, educators help guide students to develop their potential. Andragogy comes from the ancient Greek language consisting of "aner" or "andra" which means adult or adult and "ago" or "agogos" means to lead or guide, andragogy means "the art or science of guiding adults in learning". So that andragogy itself can be understood as the science of educating adults. Knowles moves from a belief that andragogy is a different form of education for children. Knowles presents andragogy as very antischooling and as liberation of adult learning participants from unhappy consequences (Usher et al., 2001).

The term andragogy comes from 'andr' which means adults which can be contrasted with 'pedagogy' which comes from 'paid' which means child and 'agogos' which means giving guidance or direction (Davenport, 1993). Many definitions are offered by experts but all of them differ from one another due to different points of view, as follows:

1. Adult education will be defined as that force which, in its ideal application, can bring about a maximum of re adjustment of attitude within a society to any new and changed situation in the shortest possible time and which helps to initiate change which evolves and imparts new skills and techniques required and made necessary by the change (Prosser, 1967).

2. Adult Education is taken to mean form of study and other activities which are undertaken voluntarily by mature people (i.e over the age of 18) without direct regard to their vocational values. They are concerned rather which development of personal abilities and aptitudes and the encouragement of social, moral and intellectual responsibility in relation to local, national and world citizenship (du Sautoy, 1968).

3. Adult Education meaning any organized provision to help adults to learn whatever they wish to learn or need to learn (Harris, 1980).

4. Andragogy as the art and science to helping adult a learner (M. S. Knowles, 1970).

The term andragogy is often found in the adult learning process, both in the non-formal education process (out-of-school education) and in the formal education learning process. In non-formal education, the theory and principles of andragogy are used as the basis for the learning process in various units, forms and levels of non-formal education. In formal education andragogy is often used in the learning process at the upper secondary education level. However, in applying the concept, the andragogy principle in the learning process does not absolutely have to be based on the form and unit level of education, but is based on the readiness of students to learn. This condition occurs because we assume that all students, students (learning participants) are adults who are assumed to have active abilities in planning the direction of learning, having materials, thinking about the best way to learn, analyzing and concluding and being able to benefit from learning. or from an educational process.

According to Knowles, the teacher's function in this case is only as a facilitator, not a teacher, so that the relationship between teachers and students (students, learning participants) is more multicommunication (M. S. Knowles, 1970). Therefore, andragogy is a form of learning that is able to give birth to learning targets (graduates) who can direct themselves and are able to become teachers for themselves. With these advantages andragogy becomes the foundation in the learning process of non-formal education. This happens because in non-formal education, the learning formula is directed at target conditions that emphasize improving life, providing skills and abilities to solve problems experienced, especially in the lives and lives of targets in the community. Sharan B. Merriam (2011) states that maturity in a person includes: age, psychological maturity, and social roles. What is meant by adult according to age, is every person who turns 21 years old (even though he is not married).

Informal programs, suggests Malcolm S. Knowles, are more likely to use a group and forum approach. Thus, education programs for adults 
began to be introduced through community centers, trade unions, industry groups and church communities. Today, the main problem that often arises is the relationship between humans. So the solution can only be found in education. Skills in human relations are skills that must be learned; it is learned at home, at school, at church, at work, and wherever people gather together in small groups. So as to form attitudes and opinions of a group, which is the foundation stone of our democracy. In the book Informal Adult Education, Knowles states that: According to Robert Maynard Hutchins, an American educational philosopher, said that "Our society cannot wait for the next generation to solve its problems. Time goes too fast. Our destiny depends on the intelligence, skill and goodwill of those who are now rulers of the citizens. The instrument that can be used to improve their ability as citizen rulers is adult education" (M. S. Knowles, 1955).

\section{Principles of the Andragori Approach in Learning}

In general, Indonesian people receive education through formal education from kindergarten, elementary, junior high, and high school, universities. However, the educational process does not only stop at formal education or school because the educational process lasts until the end of human life. In andragogy theory, learning follows certain principles according to the psychological characteristics of adults. If adult learning does not use the principles of adult education, it could be that the learning materials are not acceptable to the learning participants and the learning outcomes also do not touch the needs of the learning participants. Learning and teaching adults is not easy, because during the learning process there will be interactions between learning participants and learning resources. Learning resources can be in the form of humans, namely as facilitators and learning materials such as books, radio and television broadcasts, sound and video recordings, nature, and real life problems. In learning that involves adult learning participants, the facilitator must have knowledge of adult learning theory, he can choose appropriate learning strategies during the learning process.

Andragogy is the process of helping adults to learn optimally (Marzuki, 2010). Adult behavior is expected to foster an adaptive, independent, creative and innovative attitude accompanied by self-control. According to Knowles, adult education is different from children's education (pedagogy) (M. Knowles, 1977). Pedagogy takes place in the form of identification and imitation, while andragogy takes place in the form of selfdevelopment to solve problems. Knowles explained that there are differences between the learning activities of children and adults, here are 6 learning concepts for adults, namely; self-concept (the selfconcept); life experience (the role of the learner's experience); readiness to learn (readiness to learn); learning orientation (orientation to learning); the need for knowledge (the need to know); motivation (motivation) (M. Knowles, 1977).

These six things are the basic assumptions for making andragogy an approach that underlies the implementation and development of the current non-formal and formal educational process. Andragogy is better known as "the art and science of helping adult learn". An understanding of education is no longer just an effort to transmit knowledge, but also to form affective and develop skills as a form of lifelong learning process. Cecil Smith in his book Hand Book of Research on Adult Learning and Development (2008) argues that adult learning is related to the age and maturity level of students, socially and psychologically mature, especially in language learning, maintenance services are more important to adults. older ones, especially at the age of four (fourth head). Language teachers must have a high sensitivity to learners, especially adult learners. In the principle of andragogy learning does not start with the subject matter, but starts from the problems that occur in the life of the learning object. In this case, between educators and students exchange experiences, involving the life experiences of learning participants.

Sudjana in Gintings (2008) says that according to andragogy's view, every education must be able to assist students in: (a) creating a conducive learning atmosphere through cooperation in planning learning programs, (b) finding learning needs, (c) formulating goals and suitable material to meet learning needs, (d) designing learning patterns in a number of learning experiences for students, (e) carrying out learning activities using appropriate learning methods, techniques, and means, and (f) assessing learning activities and re-diagnosing learning needs for further learning activities. The principles of adult learning according to Anisah Basleman (2003) are as follows:

1. Readiness (readiness to learn). Students can achieve good learning outcomes, if previously the teacher prepared the condition of students both physically and mentally.

2. Sequencing (learning stages). Someone will learn more easily if the subject matter is given step by step one part from easy to difficult.

3. Understanding (understanding). A learner can learn well if he understands what he is 
going to learn, what he is learning for and what abilities he will have after he finishes studying a particular lesson.

4. Participation (participation). Learning can occur through the active participation of people who learn both physically and mentally.

5. Feed back (feedback). Learning will be more enthusiastic if participants know that the learning outcomes they have achieved may be right, not right or wrong, all of these they must know in order to improve.

6. Reinforcement (consolidation). Utilization is an important thing in the learning process, this utilization can be done with remedial or with praise.

7. Learning motivation. Learning motivation will arise when related to their needs. If you pay attention to needs, it can refer to the needs that humans have stated by Maslow. The facilitator needs to link it with the learning process.

8. Perception. Learning will be more effective if there is an attempt to connect the subject matter with the understanding or understanding that is already owned by the participants.

9. Application (application). Learning will be easier if participants see its relevance and can be applied to work situations.

10. Transfer of learning. Through the application stage, it is possible to arrive at the generalization stage, namely the use or use of learning outcomes to facilitate learning in other circumstances.

In the principle of andragogy learning does not start with the subject matter, but attention begins with the problems that occur in the life of the object of learning. In this case, the teacher and students exchange experiences, involving the life experiences of the students. With the right learning method, it is hoped that a comfortable, interesting learning atmosphere will be created and make students comfortable. This is also an effort for the success of applying the andragogy approach in language learning so as to be able to produce quality graduates.

\section{METHOD}

This type of research is quantitative. Data were taken from questionnaires, observations, interviews and learning documents. The author wants to know the effectiveness of using the andragogy method in learning Arabic for class XII at Islamic Senior High School Azzhahiriyah. The population in this study were all students of class XII in Islamic Senior High School Azzhahiriyah consisting of 34 students of class XII MIPA.1 and 35 students of class XII MIPA.2. The experimental method was carried out by taking a sample of students in class XII MIPA.2 to be given treatment with an andragogy approach in learning Arabic. While the quasi-experimental design in this study was the Nonequivalent PretestPostest Design, after which data were collected from the class that had been tested for research.

To find out the increase in student learning outcomes, a two-average difference test was conducted with the hypothesis, H0: There is no difference in the average learning outcomes of students who use the andragogy approach in learning Arabic with students who do not use the andragogy approach in learning Arabic. H1: There is a difference in the average learning outcomes of students who use an andragogy approach in learning Arabic with students who do not use an andragogy approach in learning Arabic.

\section{RESULT AND DISCUSSION}

The concept of learning Arabic with an andragogy approach is the concept of learner-centered Arabic learning. The concept includes aspects of adult selfconcept, adult experience, readiness to learn and orientation of time and direction of learning with a humanistic-based learning process and problem solving. The learning process is not centered on the teacher but centered on students as learners, the teacher acts as a facilitator. The following is the concept of learning Arabic in class XII of Islamic Senior High School Azzhahiriyah:

3.1.1. Self-concept. According to William D. Brooks in Jalaluddin Rahmat (2013) that selfconcept is our views and feelings about ourselves. This self-perception can be psychological, social and physical. Furthermore, Jalaluddin Rahmat (2013) also revealed that by observing ourselves, we arrive at our self-image and assessment, this is what is called self-concept. Selfconcept is not just observing but also judging ourselves. Students must first understand their own abilities in learning Arabic. Whether he is intelligent or has standard abilities, he must also be able to manage his time and energy in studying. In relation to learning Arabic, the teacher must know the self-concept of each student in class XII. The self-concept is described as follows: 


\begin{tabular}{|c|c|c|c|}
\hline $\begin{array}{l}\text { What is the learning } \\
\text { experience of } \\
\text { students like? }\end{array}$ & $\begin{array}{l}\text { What Arabic } \\
\text { lessons have you } \\
\text { studied? }\end{array}$ & $\begin{array}{l}\text { The purpose of } \\
\text { students learning } \\
\text { Arabic? }\end{array}$ & $\begin{array}{l}\text { What are the hopes } \\
\text { of learning Arabic } \\
\text { ? }\end{array}$ \\
\hline
\end{tabular}

The self-concept will then be used as a foothold during the learning process by the teacher in analyzing the learning needs of their students and determining goals, materials, and methods in the learning process later.

3.1.2. Experience. In the early learning process, each student shares their experiences about learning Arabic, then the teacher identifies an effective and efficient learning model for a learning class.

3.1.3. Readiness to Learn. Before learning begins, students must be really ready to learn, ready here is task and work oriented, not just knowledge.

3.1.4. Time Orientation and Learning Direction. In this concept, it focuses on the problemsolving process rather than the process of giving subjects. The Arabic learning model developed with the Andragogy approach is focused on improving the quality of the process and learning outcomes in the form of Arabic language skills. The theory that is used as the basis for developing the model is a constructivist learning theory which views language learning as a process in which students actively construct or build their language based on the knowledge of the language they already have. In other words, language learning involves constructing one's language knowledge from his own experience by himself.

According to Dr. Zainal Abidin Arief, M.Si (2015), learning strategies are specifications for selecting and sequencing events and activities in a journey. So that during the learning process the aspects developed in the learning design are objectives, materials, procedures and learning evaluations. The development of learning objectives is an effort to improve the quality of the process and learning outcomes of students' Arabic skills. The development of learning materials is directed at the development of written discourse and qawa'id contained in the topic of discussion. The development of learning procedures is directed at achieving learning objectives in the form of developing Arabic language skills training and analysis. While the development of learning evaluation is directed at developing assessment instruments that are carried out by oneself, peers and teachers.
Students as learning participants must be able to feel the value of benefits as a result of learning with an andragogy approach. In connection with the value of this benefit, class XII students, said that learning Arabic provided value for them. The results of interviews with these students found some of the benefits they got from learning Arabic as follows: 1). Make it easier to learn lessons that use Arabic, 2). Benefits for yourself and benefits for others. 3). Able to speak Arabic as an initial capital to know procedures in Arabic, can understand the Koran and Arabic books, can better understand to study and study books.

Based on the results of questionnaires, observations, interviews and learning documents, it was found that there was a significant increase in the class average in Arabic learning outcomes. Class XII MIPA.1 has a class average of 72.89 and class XII MIPA.2 which is a class that has been given learning treatment using the andragogy method has a class average of 87.45. The class average results in Arabic learning show the hypothesis that; H1: There is a difference in the average learning outcomes of students who use an andragogy approach in learning Arabic with students who do not use an andragogy approach in learning Arabic.

\section{CONLUSION}

Learning a language involves constructing one's language knowledge from one's own experience. Aspects developed in the learning design are objectives, materials, procedures and evaluation of learning. So based on the results of research in class XII MIPA 1 and class XII MIPA 2, it can be seen that there are differences in the average learning outcomes of students who use andragogy approaches in learning Arabic with students who do not use andragogy approaches in learning Arabic, and it can be concluded Arabic language using andragogy approach is an effective learning method.

\section{REFERENCES}

[1]. Abdorrakhman, G. (2008). Esensi praktis belajar dan pembelajaran. Bandung: Humaniora.

[2]. Arief, Z. A. (2015). Landasan Teknologi Pendidikan. Bogor: UIKA Press.

[3]. Basleman, A. (2003). Pendidikan orang 
dewasa. Jakarta: Program Akta Mengajar, UNJ.

[4]. Davenport, T. H. (1993). Process innovation: reengineering work through information technology. Harvard Business Press.

[5]. du Sautoy, P. (1968). The Semanticism of" Development". Community Development Journal, 3(2), 73-81.

[6]. Harris, W. J. A. (1980). Comparative adult education, practice, purpose and theory. Longman Group Limited.

[7]. Knowles, M. (1977). Adult learning processes: Pedagogy and andragogy. Religious Education, 72(2), 202-211.

[8]. Knowles, M. S. (1955). Informal Adult Education: A Guide for Administrators, Leaders, and Teachers... Association Press.

[9]. Knowles, M. S. (1970). The Modern Practice of Adult Education; Andragogy versus Pedagogy.

[10]. Majid, A., \& Rochman, C. (2014). Pendekatan ilmiah dalam implementasi Kurikulum 2013. Bandung: PT Remaja Rosdakarya.

[11]. Marzuki, S. (2010). Pendidikan NonFormal Dimensi dalam keaksaraan fungsional, pelatihan, dan andragogi. Bandung: $P T$. Remaja Rosdakarya.

[12]. Merriam, S. B., \& Brockett, R. G. (2011). The profession and practice of adult education: An introduction. John Wiley \& Sons.

[13]. Prosser, R. (1967). Adult Education for Developing Countries.

[14]. Smith, M. C., \& DeFrates-Densch, N. (2008). Handbook of research on adult learning and development. Routledge.

[15]. Sutikno, S. (2014). Metode dan Modelmodel Pembelajaran. Lombok: Holistica.

[16]. Usher, R., Bryant, I., \& Johnston, R. (2001). Self and experience in adult learning. In Supporting lifelong learning (pp. 88-100). Routledge. 